\title{
Catherine Resche, Economic Terms and Beyond: Capitalising on the Wealth of Notions
}

Bern: Peter Lang, Linguistic Insights 176, 2013

Michel Van der Yeught

(2) OpenEdition

Journals

Electronic version

URL: http://journals.openedition.org/asp/4514

DOI: $10.4000 /$ asp. 4514

ISSN: 2108-6354

Publisher

Groupe d'étude et de recherche en anglais de spécialité

Printed version

Date of publication: 1 November 2014

Number of pages: 151-154

ISSN: 1246-8185

Electronic reference

Michel Van der Yeught, " Catherine Resche, Economic Terms and Beyond: Capitalising on the Wealth of Notions », ASp [Online], 66 | 2014, Online since 27 October 2014, connection on 05 November 2020. URL : http://journals.openedition.org/asp/4514 ; DOI : https://doi.org/10.4000/asp.4514

This text was automatically generated on 5 November 2020.

Tous droits réservés 


\section{Catherine Resche, Economic Terms} and Beyond: Capitalising on the Wealth of Notions

Bern: Peter Lang, Linguistic Insights 176, 2013

Michel Van der Yeught

\section{REFERENCES}

Resche, Catherine. 2013. Economic Terms and Beyond: Capitalising on the Wealth of Notions. Bern: Peter Lang, Linguistic Insights 176. 332 pp. ISBN : 978-3-034-31435-0. 
1 The title of Catherine Resche's book, Economic Terms and Beyond: Capitalising on the Wealth of Notions, is a miniature model of what the author intends to achieve. Starting from terms, she explores the large and diversified field of economics in order to contribute to building the language content of what she names a "specialised variety of English": English for economics. Extracting semantic value from notions is akin to an enriching capitalisation process and the "Wealth of Notions" aptly echoes Adam Smith's classic An Inquiry into the Nature and Causes of the Wealth of Nations published in 1776. The author also largely capitalises on her extensive experience as a researcher and professor of economic English; her book is a clear legacy of the systematic way she

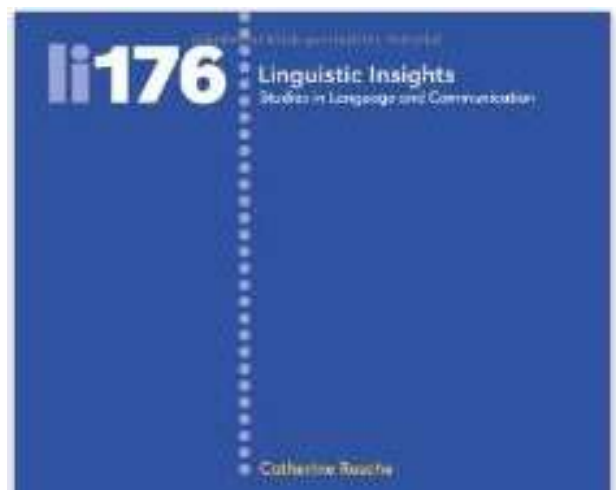

Economic Terms and Beyond: Capitalising on the Wealth of Notions

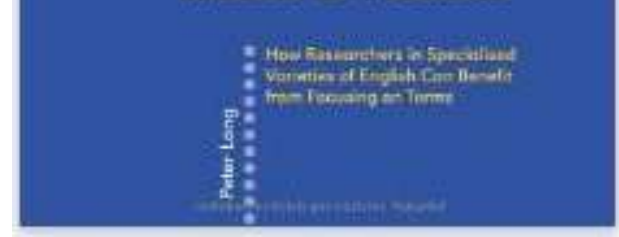
explored and taught the subject.

The volume is composed of six main sections subdivided into several chapters and subchapters. They deal with various aspects of economics and are roughly arranged according to chronological order and from-general-to-particular logic.

The first main section (numbered 2 in the contents table) clarifies the author's terminological approach. She pays homage to the ground-laying contributions of the father of modern terminology, Eugen Wüster, but relativises the dogmatism he was often blamed for. Among modern terminologists, her preference goes to Maria Teresa Cabré's "theory of doors" which helps her to build her own posture. She then introduces the concept of "Specialised Varieties of English" (SVEs) which she favours over the widely adopted notion of English for Specific Purposes (ESP).

4 Section 3 goes back to the roots of economic thinking and retraces its evolution from Antiquity to modern times. Economics derives from philosophy (Adam Smith was trained as a philosopher and thought himself to be one), but it has evolved partly by emulating other scientific disciplines which have played the role of more advanced epistemological fellow travellers: physics, mechanics, biology... As the development of economics unfolds in history, $\mathrm{C}$. Resche shows how terms are influenced by, and sometimes copy-cat, other sciences as the long-term debate between economics as a "soft" or "hard" science rolls on.

5 Section 4 focuses on neonyms as revealing signals of the discipline's evolution. Economists strive to forge new scientific concepts and the author reviews how they have performed in that respect over time. The recent subprime crisis and the emergence of "green economics" offer her contemporary case studies on how neonyms are produced in the economists' conceptual workshops.

6 Section 5 deals with metaphors in economic thinking and notably as theoryconstitutive intellectual tools. It complements Section 3 by showing how other sciences such as mechanics, hydraulic physics and biology have influenced metaphor 
production in the domain: economic phenomena are perceived as parts of machinery, as flows of capital and goods circulating in the market's pipeworks or as the result of organic energy and life cycles. More general notions such as "nature" or "liquid" are also studied as fertile grounds for metaphor building in the field.

7 Section 6 examines the particular problem posed by fuzzy intellectual tools such as indeterminate terms, paradoxes, puzzles, oxymora and misnomers. Is fuzziness a foe of scientific clarity or does it play a useful intellectual role? The author shows that it often does as it exposes ambiguities and conundra that are sometimes too conveniently plastered over by general theories. The case of euphemisms in economics (a prolific offshoot sometimes called "euphenomics") illustrates the Jesuistic discursive strategies elaborated by high officials to reconcile hard economic facts with palatable public policies.

8 Section 7 studies "interface terms" that help economics to relate, combine and crossfertilise with other disciplinary domains such as the social, physical and natural sciences already mentioned in previous sections. Complementary chapters enrich the research by exploring cross-disciplinary terminological interactions among economics, linguistics and chaos theory.

9 Sections are handled in a highly methodical way, always opening on the relevant founding definitions and fundamental issues before branching out into more detailed discoveries and discussions. The reader sets sail on the vast ocean of economic terminology equipped with numerous quotations, references, tables, figures and diagrams. The volume comes with twenty-nine pages of references, a subject index and an author index.

10 It would be impossible, and probably tedious, to list all the merits of this quasiexhaustive analysis of hundreds of economic terms, coined over centuries by scores of thinkers belonging to many different intellectual schools and trends, but the reviewer shortlists three as worthy of attention in his opinion.

11 The first one is theoretical. It is apparently one of the first times the notion of Specialised Variety of English (SVE) has been so thoroughly harnessed to research English for economics. Although occasionally used by ESP scholars (Anthony 2011: 4; Isani 2013: 193), the notion was given a more theoretical status in a definition of specialised languages adopted in 2011 by the French society for the study of English in higher education (SAES). ${ }^{1}$ The author highlights the merits of ESP approaches but she shows that they limit her own work by focusing primarily on pedagogical concerns (pp. $14,42)$. As she teaches the students of a multi-century-old discipline in an exogenous (French) learning context (Isani 2013: 194), she takes the view that specialist knowledge is essential in the teaching of English for economics and the SVE notion fully serves her objectives. It introduces a paradigm shift of sorts in that learners' needs no longer operate as the organising principle of knowledge building, but are replaced in that function by the inner logic of the specialised domain itself. Learners come and go and so do their needs, but economic terms and theories last much longer and have a life of their own. The notion of SVE provides the linguistic stability which is required to analyse them seriously. Laurence Anthony (op. cit.) argues in favour of a "wider-angled" approach to specialised languages; $C$. Resche opts for the narrow-angled one, and, if asked how much specialist knowledge an SVE teacher should know, her answer is: quite a lot. 

specialised domains in English (pp. 13, 284), she builds the terminological component of the economic SVE - a daunting task since many ESP scholars are loath to elaborate on specialised domains lest they be suspected of playing specialists. Cutting a fine line between language concerns (text, discourse, genres, style...) and economics, she creates a new type of SVE knowledge which is neither purely English, nor economics, but precisely that, the "expression of economics" in the terms of the English language. Thus, she points to a way out of the enduring debate between the proponents of language-vs-content solutions to address the problem of course building in specialised languages. Her answer is that the researchers' job is to produce specific SVE knowledge from which teachers may pick what they observe is relevant to meet their learners' needs. As a result of this epistemological balancing act, she makes sense of umpteen economic terms while always from the linguist's standpoint and not from the economist's. The suggestion that her approach could be applied to other SVEs (p. 14) is convincing and the book will no doubt operate as a role model for future like-minded authors. research ventures in specialised languages which convincingly addresses the problem of diachrony. The temporal dimension is too rarely taken into account in ESP research. Tellingly, the latest reference publication in the field, The Handbook of English for Specific Purposes (Paltridge \& Starfield 2013) has no index entries for synchrony and diachrony, and its "history" entry only lists passages referring to time in relation to ESP research, not in relation to the specialised languages themselves. C. Resche shows that many economic terms have complex and meandering genealogies and that one cannot ignore their history when it comes to understanding and teaching them seriously. Of course, she devotes most of her developments to contemporary cases and studying the diachronic dimension of specialised languages is sometimes irrelevant when, say, one teaches English to Indian power station operators (Halliday et al. 1964: 190). Still, mature SVEs such as legal, economic and financial English have been forged through centuries of reflection and debate and the SVE teacher should have some grasp of the diachronic evolutions of their contemporary terms to make sense of their present meanings.

14 Finally, two observations may help balance the picture. The first is that readers interested in SVEs might have welcomed a more clear-cut definition of the notion. As it stands, the presentation of $\mathrm{SVEs}^{2}$ leaves the reader to decide whether, in the last analysis, the actual substance of an SVE is the specialised domain (here economics), or language (which the reviewer assumes), or perhaps the dynamic of the research itself. In other words, and in that particular case, are terms the very object of the research or are they just gateways leading to the ultimate finality of the exploration, the description of the specialist domain? In that respect, a clarification would help those colleagues willing to emulate the book and apply the author's approach to other SVEs.

The second is that, thick as it is, the economic terminological tree should not hide the vast forest of the SVE. The magnitude of C. Resche's undertaking makes terms the entry points of choice to many other aspects of English for economics. However, assuming SVEs are complex mixes of language, discourse and culture, these dimensions should be fully studied in their own right as well, if a full description of the economic SVE is to be achieved. Economic Terms and Beyond may be the foundation stone of this wider project. 
Most encouragingly, it generously provides the heavy fuel needed to launch such future research explorations.

\section{BIBLIOGRAPHY}

Anthony, Laurence. 2011. "Products, processes and practitioners: A critical look at the importance of specificity in ESP". Taiwan International ESP Journal 3/2, 1-18.

Commission formation de la SAES. 28 janvier 2011. "Évolution et enjeux des formations et de la recherche dans le secteur LANSAD”. Accessed 21 September $2014<\mathrm{http}: / /$ sha.univ-poitiers.fr/ saesfrance/spip.php?article262>.

Halliday, M. A. K., A. McIntosh \& P. Strevens. 1964. The Linguistic Sciences and Language Teaching. London: Longmans.

Isani, Shaeda. 2013. "Quo vadis? Past, present and future aspects of ESP”. A review of Ë, Brian \& Sue Starfield (eds.), The Handbook of English for Specific Purposes. Boston: Wiley-Blackwell. ASp 64, 192-198.

Paltridge, Brian \& Sue Starfield (eds.). 2013. The Handbook of English for Specific Purposes. Boston: Wiley-Blackwell.

\section{NOTES}

1. Une variété spécialisée de l'anglais, souvent appelée langue de spécialité par commodité, est l'expression d'un domaine spécialisé dans cette langue (SAES, Commission formation 2011).

A specialised variety of English, often called Specialised English for short, is the expression of a specialised domain in the English language (reviewer's translation).

2. "[...] but the ultimate goal is to provide as detailed and comprehensive a description as possible of a given specialised field through language as an entry point" (p. 14). See also, pp. 43, $45,284$.

\section{AUTHORS}

\section{MICHEL VAN DER YEUGHT}

Aix-Marseille Université, LERMA EA 853. michel.vanderyeught@univ-provence.fr 